\title{
Utilizing magnesium based materials to reduce green house gas emissions in aerospace sectorss
}

\begin{abstract}
This article highlights the importance of light weighting option in aerospace sector as an effective measure of reducing the carbon dioxide emission. Various methods of reduction in fuel consumption in aerospace sector are highlighted. Use of magnesium based materials as replacement for aluminum based materials and fiber based composites for light weighting is highlighted with an example. Myths of ignitability and flammability are dispelled by directing the attention of the readers to the inherent thermal properties of magnesium in bulk form and through highlighting the past and present use of magnesium based materials in both fighter and commercial aircrafts. Information is also provided on the availability of some coating techniques that can bring the corrosion resistance of magnesium based materials at par with aluminum based materials.
\end{abstract}

Volume I Issue I - 2017

\author{
Manoj Gupta,' Neelabh Gupta² \\ 'Department of Mechanical Engineering, National University of \\ Singapore, Singapore \\ ${ }^{2}$ Department of Materials Science and Engineering, Nanyang \\ Technological University, Singapore
}

Correspondence: Manoj Gupta, Department of Mechanical Engineering, National University of Singapore, 9 Engineering Drive I, Singapore, Tel (65) 6516 6358, Email mpegm@nus.edu.sg

Received: May 31, 2017 | Published: June 27, 2017
Abbreviations: $\mathrm{CO}_{2}$, carbondioxide; ASTM, american society for testing and materials; OEW, operating empty weight; PBR, pilling-bedworth ratio; $\mathrm{Mg}$, magnesium; LCA, light combat aircraft; FAA, federal aviation administration

\section{Introduction}

Aviation sector is one of the fastest growing sector globally in terms of both passenger and cargo traffic. Boeing has predicted that over next 20years there will be an additional need of over 39600 airplanes valued at more than $\$ 5.9$ trillion. ${ }^{1}$ However, the growth in aerospace sector poses the challenge of global warming through greenhouse gas emissions. Aviation sector currently rank in the top 10 emitters of greenhouse gases (principally $\left.\mathrm{CO}_{2}\right)^{2}$ and accounted for $3 \%$ of the warming. ${ }^{3}$ These emissions are likely to increase in coming years due to the expansion of aerospace sector. To mitigate this effect, the aviation industry is targeting to improve fuel efficiency by $1.5 \%$ each year until 2020 and aiming to stop any further emission growth beyond that. ${ }^{3}$ Considering that the aerospace sector is rapidly expanding, controlling $\mathrm{CO}_{2}$ emissions can be a challenging task. To also note is that international efforts like Paris agreement aims to reduce emission of carbon dioxide by 2 billion tons by 2025 and to keep the temperature increase within $2^{\circ} \mathrm{C}$ from the pre-industrial levels which will undeniably put significant pressure on the aerospace sector to reduce $\mathrm{CO}_{2}$ emissions through a holistic approach.

\section{Methods of minimization of fuel consumption}

The fuel efficiency in aerospace sector can be improvised by undertaking a number of measures that include:

\section{i. Structural optimization.}

Use of fuel efficient engines. This includes replacing large engines with smaller engines and using less polluting turbofan and turboprop engines.

Use of biofuels mixtures. ${ }^{3}$ This includes the use of jatropha, algae, coconut oils, and ethanol. The renewable fuels can be blended with conventional commercial and military jet fuel. The requirements are stated in ASTM D7566, Specification for Aviation Turbine Fuel
Containing Synthesized Hydrocarbons. Besides liquefied natural gas is also being tried in some airplanes. ${ }^{4}$

Use of lightweight materials in areas such as airframe and seats.

Through implementing government and international aviation policies such as carbon tax.

Enhancing seating strategies by reducing business and first class seats. It has been established that the carbon footprints of business class and first class are three-times and nine-times higher than that of economy class. ${ }^{4}$

Optimization of airline timetables, route networks and flight frequencies to minimize the number of empty seats flown together with the optimization of airspace. ${ }^{4}$ These also include landing and takeoff times.

Discontinuing frequent flyer programs as they prompt the people to travel more than required due to added incentives. These are in direct conflict with society's long term well being.

All these factors (design, materials, operational and governmental) are worthy of serious investigation for enhancing fuel efficiency and are being pursued by concerned parties worldwide. Besides, it is clear that climate changes including that arising from greenhouse gas emissions are serious concerns that need to be addressed. Among the aforementioned options, the use of lightweight materials such as magnesium based alloys and composites holds a strong promise in the immediate future for greenhouse gas emission reduction and will be targeted in this paper. Having said that, a holistic approach will be address all the factors mentioned above simultaneously.

\section{Materials distribution in a typical aircraft}

Boeing and Airbus are two large manufacturers of commercial aircrafts. In common they use aluminum, steels, titanium, composites and other elements. A typical material distribution from these manufacturers is shown in the Table $1.5,6$

The typical density of these materials is shown in Table 2. This table shows the density of principal elements to reflect their weight. ${ }^{7-9}$ 
A typical Operating Empty Weight (OEW) for Boeing 747 passenger model is indicated to be $\sim 213 \mathrm{t}(213000 \mathrm{~kg}) .{ }^{10}$ Boeing 747 uses about $81 \%$ aluminum $(172530 \mathrm{~kg})$. Assuming aluminum alloys are replaced completely (100\%) by magnesium alloys, it will translate to a $60385 \mathrm{~kg}$ $(\sim 60.4 \mathrm{t})$ reduction and if it is replaced by $50 \%$ by magnesium alloys, it will translate to $30192 \mathrm{~kg}(\sim 30.2 \mathrm{t})$ reduction. Similar calculations can be made for replacing Fiberglass composites and fiber metal laminates which are heavier than magnesium (Table 2).

Table I Typical materials distribution in commercial aircrafts

\begin{tabular}{|c|c|c|c|c|}
\hline Materials & $\begin{array}{l}\text { Boeing } \\
777 \\
(5)\end{array}$ & $\begin{array}{l}\text { Boeing } \\
787 \\
(5)\end{array}$ & $\begin{array}{l}\text { Airbus } \\
\text { A380 } \\
\text { (6) }\end{array}$ & Remarks $(5,6)$ \\
\hline Aluminum & 70 & 20 & 61 & $\begin{array}{l}\text { Used in airframe } \\
\text { and also stress } \\
\text { bearing members. }\end{array}$ \\
\hline Titanium & 7 & 15 & 10 & $\begin{array}{l}\text { Where strength, } \\
\text { damage tolerance } \\
\text { and high } \\
\text { temperature is } \\
\text { important }\end{array}$ \\
\hline Steel & 11 & 10 & & $\begin{array}{l}\text { Where high } \\
\text { strength is a must. }\end{array}$ \\
\hline Composites & 11 & 50 & 22 & $\begin{array}{l}\text { Includes } \\
\text { fiberglass, } \\
\text { carbon laminate } \\
\text { composites and } \\
\text { carbon sandwich } \\
\text { composites in } \\
\text { Boeing. }\end{array}$ \\
\hline Others & I & 5 & 5 & $\begin{array}{l}\text { For A380 it } \\
\text { includes Fiber- } \\
\text { Metal laminates. }\end{array}$ \\
\hline
\end{tabular}

Table 2 Density of base materials used in commercial aircrafts

\begin{tabular}{ll}
\hline Materials & Density $(\mathrm{g} / \mathrm{cc})$ \\
\hline Magnesium & 1.74 \\
Aluminum & 2.7 \\
Titanium & 4.5 \\
Steel & 7.87 \\
Fiberglass Composite & $1.9(\mathrm{E} \text {-glass/Epoxy })^{7}$ \\
Carbon laminate composite & $1.6\left(\mathrm{~V}_{\mathrm{f}}=60 \%\right)^{8}$ \\
Fiber metal laminate (GLARE) & $2.43^{9}$ \\
\hline
\end{tabular}

\section{Justifying the use of magnesium}

Magnesium is the lightest metallic element capable of serving both structural and non-structural applications. It can provide a weight saving of $\sim 33 \%$ against aluminum and $\sim 77 \%$ against steels. ${ }^{11}$ This will translate into a lighter aircraft and reduced fuel consumption coupled with lower $\mathrm{CO}_{2}$ emissions. Illustrating the amount of fuel used, it has been reported that heavier the aircraft (e.g. more number of seats), more will be the fuel burnt per passenger ${ }^{12}$ (Table 3).
Table 3 Fuel burnt per passenger for different aircrafts of same company

\begin{tabular}{lll}
\hline Aircraft type & Number of seats & $\begin{array}{l}\text { Fuel burnt per } \\
\text { passenger }\end{array}$ \\
\hline B 767 - 300 ER & 218 & $98.4 \mathrm{~kg}$ \\
B 747 - 400 & 416 & $102.4 \mathrm{~kg}$
\end{tabular}

The amount of fuel burnt can be translated into $\mathrm{CO}_{2}$ emission as $1 \mathrm{~kg}$ of jet fuel burnt equals to $3.15 \mathrm{~kg}$ of $\mathrm{CO}_{2}$ emission. ${ }^{2}$ While light weighting is a clear and present option, it is also important to assess the additional industrial adaptability options for magnesium based materials such as:

1) Availability of magnesium.

2) Toxicity of magnesium.

3) Processing aspects of magnesium.

4) Recyclability.

5) Maintenance of magnesium based materials when in service.

Magnesium is an abundantly available element on planet earth (both land and water bodies) and in the universe. ${ }^{14-16}$ Its availability is almost 13 times that of aluminum by mass and hence ensures the sustainability of its applications in aerospace sector.

Magnesium is also a nutritional element for humans, animals and plants. It is fourth most abundant cation in human body and mainly stored in bones. ${ }^{17}$ In humans it is important for muscles, nerves, cardiovascular system, and immune system and is involved in 300 chemical reactions in the body. This indicate that magnesium will not need any special infrastructure for recycling and its entry into food chain will only improve the health of living organisms including humans. Thus the use of magnesium based materials will also enable researchers to follow professional ethics by not straining the climate and in providing a better world to our future generations. On the contrary, aluminum is neurotoxic and its use must be minimized. Intake of aluminum may lead to cognitive deficiency, dementia, adverse effect on central nervous system and reproductive system. ${ }^{17,18}$ Accordingly, the recycling of aluminum will need technological efforts and its presence in food chain will only be detrimental to living organisms.

Magnesium based materials can be primarily processed using both liquid based and powder based methods. Infrastructure similar to aluminum alloys can be used with minor modifications as both magnesium and aluminum based materials exhibit similar melting points. For secondary processing based on plastic deformation, forging, rolling and extrusion can be carried out using the existing infrastructure used for aluminum alloys though with different processing parameters. Similarly, magnesium exhibit excellent machinability. It can be milled at high speeds and ensures improved tool life (5-10 times longer). The ability of magnesium to be converted into a finished product faster ensures lesser production time and hence ensures cost savings in terms of labor cost. ${ }^{11}$

As magnesium is not a toxic element and it is electrochemically active, its recyclability is not an issue. It can be assimilated back into nature without the need to develop any specialized facilities. Its entry into food chain will only bring beneficial effects to both plants and animals as discussed earlier. ${ }^{17-19}$ 
Magnesium is an electrochemically active element located almost at the bottom of galvanic series. Under dry condition, it exhibits a Pilling-Bedworth Ratio (PBR) equals to 0.8. A PBR ratio of $<1$ indicates a non-protective oxide on the surface which has limited ability to minimize corrosion once formed. ${ }^{20}$ This indicates that magnesium will corrode under both dry and wet atmospheric conditions unless it is intrinsically (controlling composition) or extrinsically protected (e.g. use of anodizing or coatings). This is similar to the way we protect aluminum and steels. The only difference is that corrosion protection technologies are very mature for aluminum and steels while more work is required in the case of magnesium based materials. To note that such technologies if available in public domain will do a larger good to human society by not only enhancing the increased application of magnesium in aerospace sector but also in other sectors. This will, however, depend on the willingness of the private companies to release the required and patented technology in public domain.

\section{Magnesium based materials were used in both in past and current aircrafts}

Table 4 summarizes that magnesium based materials were used extensively in past and also in many current applications in aerospace sector. Both Russian and American aerospace industry used magnesium in past, however; their full potential in aerospace sector is not yet fully utilized. If anything has to be learnt from the past than the fact that no failure or accident was reported in any literature in public domain where any of the magnesium based materials was the key factor causing a failure. ${ }^{21}$

Table 4 History and current trends of magnesium in aerospace sector

\begin{tabular}{|c|c|c|c|}
\hline Type of aerospace vehicle & Role & Years of operation & Use of magnesium \\
\hline Convair XC-9922,23 & $\begin{array}{l}\text { Cargo and troop } \\
\text { Movement }\end{array}$ & 1940 s and 1950 s & Magnesium alloy skin in airframe. \\
\hline Convair B-36 24 & Bomber & $1949-1959$ & Used a total of $8600 \mathrm{~kg}$ of magnesium. \\
\hline Sikorsky S-56 ${ }^{25}$ & Cargo helicopter & 1950 & Used II 5 kg of magnesium. \\
\hline Lockheed F-80C 26,28 & Fighter jet & 1945 & Fully built of magnesium \\
\hline Tupolev TU-95 27 & Bomber & 1952 till present & Used about $1550 \mathrm{~kg}$ of magnesium. \\
\hline TU-I34'I & $\begin{array}{l}\text { Russian commercial } \\
\text { aircraft }\end{array}$ & 1963 onwards & $\begin{array}{l}\text { Employed I } 325 \text { magnesium components } \\
\text { with a total weight of } 780 \mathrm{~kg}\end{array}$ \\
\hline Boeing B-52 Stratofortress ${ }^{28}$ & Strategic bomber & 1952 onwards & $\begin{array}{l}\text { Used } 5534 \mathrm{~kg} \text { of magnesium sheet } \\
\text { components, } 680 \mathrm{~kg} \text { of magnesium forgings } \\
\text { and } 300 \mathrm{~kg} \text { of magnesium castings. }\end{array}$ \\
\hline Boeing $727^{29,30}$ & Commercial aircraft & $1962-1984$ & I 200 magnesium parts. \\
\hline Piper Chieftan ${ }^{29,31}$ & Family aircraft & $1967-1984$ & AZ9I E castings. \\
\hline Piper Comanche ${ }^{32}$ & Family aircraft & $1957-1972$ & AZ9I E castings. \\
\hline Light combat aircraft ${ }^{33}$ & Multirole fighter & Inducted in 2015 & RZ-5 magnesium gear box. \\
\hline Sikorsky UH-60 Black Hawk ${ }^{34}$ & Medium-lift Helicopter & I974 to present & ZE $4 \mathrm{I}$ alloy in main transmission. \\
\hline Sikorsky CH53D helicopter ${ }^{36}$ & Heavy-lift helicopter & $1966-2012$ & $285 \mathrm{~kg}$ of AZ 9IE castings. \\
\hline Boeing CH 47 Chinook helicopter ${ }^{37}$ & $\begin{array}{l}\text { Heavy-lift transport } \\
\text { helicopter }\end{array}$ & I962 till resent & Used ZE 4I castings. \\
\hline Boeing AH 64 Apache Helicopter ${ }^{38}$ & Attack helicopter & 1986 till present & Used ZE 4I castings. \\
\hline Bell Augusta 609 tilt rotorVTOL aircraft ${ }^{39}$ & VTOL aircraft & First flight March 6, 2003 & WE43 castings in gear box. \\
\hline
\end{tabular}




\section{Key challenges to enhance the use of magnesium in aerospace}

While there is a rich history of use of magnesium based materials in aerospace sector as can be seen from Table 4 , its full potential is not realized. ${ }^{22-39}$ The key reasons may be:

a. Perceived psychological fear of flammability of magnesium.

b. Limited number of commercial magnesium based materials.

c. Corrosion susceptibility of magnesium based materials.

For various reasons, there is a false perception that magnesium can easily catch fire. Magnesium catches fire beyond its melting point $\left(650^{\circ} \mathrm{C}\right.$ for pure $\left.\mathrm{Mg}\right)$. Ignition temperature of pure magnesium is about $580^{\circ} \mathrm{C}$ in air. Such temperatures are difficult to realize in most of aircraft structure except for engine area. Table 2 shows the types of materials used in a typical commercial aircraft. Maximum service temperature of some of polymer based composites is shown in Table 5. ${ }^{40,41} \mathrm{It}$ can be seen that maximum service temperature remains at $\sim 220^{\circ} \mathrm{C}$ which is much lower than the ignition/flammability temperature of pure magnesium. This indicates that before magnesium ignites, the structure of the aircraft would have failed already. Also to note that all electronic materials used in aerospace including lead and lead free solders $^{42}$ exhibit much lower melting temperature $\left(<230^{\circ} \mathrm{C}\right)$ when compared to any of the magnesium alloy. This temperature is similar to the maximum working temperature of polymer based composites suggesting that all the electronics control will fail beyond $230^{\circ} \mathrm{C}$. These two indicators suggest that thermal stability of magnesium based materials is far superior to many materials used in a typical aircraft that are critical for its reliable functioning.

The main limitation to a materials selector is to find a wide range of magnesium alloys capable of exhibiting diverse combination of properties as required by different applications. Both steels and aluminum alloys provide a wide choice. Over last 15years, tremendous efforts have been made by researchers worldwide and

Table 5 Maximum service temperature shown by polymer based composites

\begin{tabular}{|c|c|c|}
\hline \multirow[t]{2}{*}{ Material } & \multicolumn{2}{|c|}{ Service temperature $\left({ }^{\circ} \mathrm{C}\right)$} \\
\hline & Minimum & Maximum \\
\hline Carbon fiber/Epoxy (SMC) & & $166-184$ \\
\hline HS Carbon fiber/Epoxy $\left(0^{\circ}\right.$ Unidirectional lamina $)$ & & $* \mid 40-220$ \\
\hline HS Carbon fiber/Epoxy ( $90^{\circ}$ Unidirectional lamina) & & $* 140-220$ \\
\hline HS Carbon fiber/Epoxy ( $90^{\circ}$ Unidirectional lamina) $(0 /+45 /-45 / 90)$ & & $* \mid 40-220$ \\
\hline HS Carbon fiber/Epoxy ( $0^{\circ}$ Bidirectional lamina) & $(-123)-(-73)$ & $* 140-220$ \\
\hline HS Carbon fiber/Epoxy $\left(90^{\circ}\right.$ Unidirectional lamina) $(0 / 90,+45 /-45)$ & & $* \mid 40-220$ \\
\hline Glass fiber/Epoxy (SMC) & & $* 170-190$ \\
\hline E-Glass fiber/Epoxy (0/90 Biaxial lamina) & & $* 140-220$ \\
\hline Glass fiber/Epoxy (unidirectional) & & $* 170-190$ \\
\hline
\end{tabular}

private companies such as Magnesium Elektron to develop and use new magnesium based materials. Progress is also made in using composite technology to enhance the properties of magnesium besides compositional adjustments. For example, Mg- $4 \mathrm{Zn}-3 \mathrm{Gd}-1 \mathrm{Ca} / 2 \mathrm{ZnO}$ nanocomposite exhibit strengths that exceed that of commercial magnesium alloys (i.e. WE43, WE54, ZK60, and ME21) and mild steels (i.e. S275 and S355). ${ }^{43}$

As indicated earlier, corrosion is one of the main issue that is faced by magnesium and its alloys while in service in the past. ${ }^{21,29,30,44-47} \mathrm{It}$ is also important from a maintenance perspective and hence the use of corrosion resistant alloys and corrosion management system for magnesium based materials is of paramount importance. A reduction in corrosion susceptibility and maintenance cost is likely to assist the use of magnesium based materials in aerospace applications. The corrosion susceptibility can primarily be avoided by:

i) Use of proper alloy and

ii) Use of corrosion protection methods such as coatings.

Magnesium alloy RZ-5, for example, is used in the gear box in LCA-Tejas a fighter aircraft inducted in Indian Air Force recently. It was subjected to various tests like salt fog test, sand and dust tests and did not show any problem in more than 2200 hours of flight testing with 1465 flights. Efforts have been made in past, for example, to develop coatings which brings magnesium based materials at par with aluminum alloys. ${ }^{21}$ Proprietary coatings such as HAE, DOW 17 and unsealed Tagnite coatings are also used to protect magnesium based materials. ${ }^{48,49}$ In addition, advanced design concepts have to be utilized to eliminate galvanic corrosion if the magnesium component is joined with component made of other material. Ensuring this will avoid the failures like experienced by Royal Navy Sea Harriers when they returned from Falkland conflict. ${ }^{50}$ The galvanic failure of the nose wheels was attributed to the coupling of magnesium alloy wheel hub and stainless-steel bearing. Grounding and local surface protection technologies have to be established as these are applicable to most of aeronautic components. ${ }^{51}$ 
Table 6 Corrosion issues in aircrafts and helicopters

\begin{tabular}{lll}
\hline $\begin{array}{l}\text { Type of } \\
\text { aircraft }\end{array}$ & Corrosion problem & Remarks \\
\hline Convair XC-99 & Deterioration of Airframe & $\begin{array}{l}\text { Beyond the local abilities to address. Phased out } \\
\text { in I957. }\end{array}$ \\
Convair B-36 & $\begin{array}{l}\text { Airframe and skin did not age well due } \\
\text { to magnesium alloys }\end{array}$ & $\begin{array}{l}\text { Acrylic paint was used to protect the skin from } \\
\text { corrosion }\end{array}$ \\
$\begin{array}{l}\text { UH } 60 \text { Black } \\
\text { Hawk }\end{array}$ & Corrosion of magnesium parts & $\begin{array}{l}\text { These parts have to be removed prematurely. } \\
\text { High maintenance and replacement cost. Absence } \\
\text { of restoring technology. }\end{array}$
\end{tabular}

\section{A typical example of weight saving through replacement of aluminum alloy seats by magnesium alloys}

Following the FAA conditional approval of using magnesium based materials in aircraft cabin in seat construction, ${ }^{51}$ immediate calculations were made on weight saving that can potentially be realized with such an exercise. It has been reported that aluminum alloys account for $40 \%$ of the total weight of a typical economy class aircraft seat. This can be replaced by magnesium alloys through redesigning resulting in about $30 \%$ weight saving. This translates into $360 \mathrm{~kg}$ weight saving for a typical 117-seat narrow body Airbus A318 and up to $4200 \mathrm{~kg}$ for a 700 seat Airbus A380 wide body plane. ${ }^{52,53}$ To note is that there are also many other areas for aluminum alloys replacement in an aircraft such as in unit loading devices and will depend on the combined vision of a design/structural engineer and a materials engineer.

\section{Concluding remarks}

Aerospace sector is one of the significant contributors of greenhouse gas emissions. Ligtweighting is one of the methods to reduce the emissions of $\mathrm{CO}_{2}$. Magnesium based materials including composites provide a suitable option. The approval of FAA in easing the restriction of usage of magnesium in seats construction in 2015 is a positive step forward to minimize the technological stress on environment and is likely to pave the way for the larger role of greener magnesium technology in the very near future.

\section{Acknowledgements}

None.

\section{Conflict of interest}

Author declares that there is no conflict of interest.

\section{References}

1. http://www.boeing.com/resources/boeingdotcom/commercial/about-our-market/assets/downloads/cmo_print_2016_final.pdf

2. Reducing emissions from aviation Policy, Climate Action, European Commission.

3. Aviation Industry Outlines Ambitious Climate Goals. Worldwatch Institute, Washington, USA.

4. Environmental impact of aviation.

5. What materials make up most of the weight of an aircraft. Aviation Stack Exchange.
6. https://www.google.co.th/search? $\mathrm{q}=\mathrm{g} \&$ oq $=\mathrm{g} \& \mathrm{aqs}=$ chrome.0.69i591$3 \mathrm{j} 69 \mathrm{i} 6013.4891 \mathrm{j} 0 \mathrm{j} 9 \&$ sourceid $=$ chrome \&ie $=U \mathrm{TF}-8 \# \mathrm{q}=$ materials + used + in + airbus + a 380

7. Mechanical Properties of E-glass/Epoxy.

8. Mechanical Properties of Carbon Fibre Composite Materials, Fibre / Epoxy resin $\left(120^{\circ} \mathrm{C}\right.$ Cure $)$.

9. Ground breaking aircraft structures. Fokker Aerostructures Inc. Washington USA.

10. Jon Ostrower. Boeing increases 747-8 family weights. Air Transport Intelligence news, Flight Global, Washington, USA; 2012.

11. M Gupta, Sharon Nai. Magnesium, Magnesium Alloys and Magnesium Composites. John Wiley \& Sons Publishing company, New Jersey, United States; 2011. p. 280.

12. Examples of Different Aircraft Types' Fuel Burn Rate. Stockholm Environment Institute and Greenhouse Gas Management Institute 2011

13. IATA Carbon Offset Program. FAQ Airline Participants. IATA Publishers. 2015. p. 1-11.

14. G Neite, K Kubota, K Higashi, et al. Magnesium-Based Alloys. In: Materials Science and Technology, Wiley-VCH Verlag GmbH \& Co, Germany; 2006.

15. Lea Porteous, Charlie Wang. Case Study: The Natural Abundance of Elements. University of California, USA; 2014.

16. 10 Most Abundant Elements in the Universe.

17. M Gupta, GK Meenashisundaram. Insight into Designing Biocompatible Magnesium Alloys and Composites. 2015.

18. Masahiro Kawahara, Midori Kato Negishi. Link between Aluminum and the Pathogenesis of Alzheimer's Disease: The Integration of the Aluminum and Amyloid Cascade Hypotheses. Int J Alzheimers Dis. 2011.

19. Magnesium - Important for Every Stage of Plant Growth.

20. MG Fontana and ND Greene. Corrosion Engineering. 2nd edn. McGraw Hills, New york, USA; 1982.

21. I Ostrovsky and Y Henn. New Challenges and Future of Magnesium Application in Aerospace Industry. Proceedings of International Conference "New Challenges in Aeronautics". ASTEC'07, Moscow, Russia; 2007.

22. Aircraft-Convair_XC-99.

23. Historic American Engineering Record, Kelly Air Force Base, Texas, USA.

24. Convair_B-36_Peacemaker

25. Sikorsky_CH-37_Mojave.

26. Lockheed_P-80_Shooting_Star. 
27. Tupolev_Tu-95.

28. Boeing_B-52_Stratofortress.

29. B Gwynne and P Lyon. Magnesium Alloys in Aerospace Applications, Past Concerns, Current Solutions. Triennial International Aircraft Fire \& Cabin Safety Research Conference. 2007.

30. M Pekguleryuz. Fundamentals of Magnesium Alloy Metallurgy. Woodhead Publishing, Cambridge, UK; 2013. p. 287-288.

31. PA-31_Navajo.

32. Piper_PA-24_Comanche.

33. HAL_Tejas.

34. Sikorsky_UH-60_Black_Hawk.

35. Sikorsky_S-92.

36. Sikorsky_CH-53_Sea_Stallion.

37. Boeing_CH-47_Chinook.

38. Boeing_AH-64_Apache.

39. AgustaWestland_AW609.

40. C.E.S. Edupack. Aerospace Database (Software) Granta Design Ltd., Cambridge, UK; 2016.

41. AMSC N, CMPS AA. Composite Materials Handbook. 2002. p. 693.
42. David A Pinsky. How The Aerospace Industry Is Facing The Lead-free Challenge. Aerospace Industries Association. 2006.

43. Y Chen, S Tekumalla, YB Guo, et al. Introducing $M g-4 Z n-3 G d-1 C a /$ $\mathrm{ZnO}$ Nanocomposite with Compressive Strengths Matching/Exceeding That of Mild Steel. Scientific Reports 6, Article number 32395. 2016. p. $1-5$.

44. Convair XC-99 Transport and Model 37 Airliner.

45. KU Kainer. Magnesium Alloys and Their Applications. Wiley VCH, Germany; 2000. p. 798.

46. Dennis R Jenkins. Magnesium Overcast: The Story of the Convair B-36. Specialty Press, Minnesota, USA; 2001. p. 276.

47. http://www.arl.army.mil/www/default.cfm/default.cfm?article=744

48. Effects of Corrosion.

49. Elke Hombergsmeier ,MAGNESIUM FOR AEROSPACE APPLICATIONS, EADS Deutschland Innovation Works

50. Trethewey, Chamberlain. Historic Corrosian Lesson. 1988.

51. https://www.runwaygirlnetwork.com/2015/08/20/magnesium-alloys-tobe-used-in-aircraft-seats-as-ban-is-lifted/

52. F Czerwinski. Controlling the Ignition and Flammability of Magnesium for Aerospace Applications. Corrosion Science 2014;86:1-16.

53. I Stachel. Light Weight Alloys in Seat Design, Influence of Magnesium in Seats. 2016. p. 1-11. 